\title{
PENYELENGGARAAN REKAM MEDIS PADA PELAYANAN KESEHATAN BAKTI SOSIAL OLEH RUMAH SAKIT UMUM DAERAH KABUPATEN TEMANGGUNG
}

\author{
Nanik Puji Rahayu, Sofwan Dahlan dan Petrus Soerjowinoto \\ Nanikpujirahayu@yahoo.com \\ Magister Hukum Kesehatan \\ Universitas Katolik Soegijapranata Semarang
}

\begin{abstract}
ABSTRAK
Dalam mewujudkan kesejahteraan kesehatan tentunya diperlukan upaya-upaya seperti promotif, preventif, kuratif dan rehabilitatif. Rumah sakit merupakan institusi kesehatan yang menyenggarakan pelayanan kesehatan kepada seseorang secara paripurna. Selain itu rumah sakit juga memiliki fungsi sosial yang diwujudkan dalam bentuk pelayanan kesehatan kepada masyarakat tanpa adanya pungutan biaya atau bakti sosial pelayanan kesehatan. Rumah sakit mempunyai kewajiban dalam penyelenggaraan rekam medis, baik dalam pencatatan hasil kegiatan pelayanannya maupun pendokumentasian hasil pelayanan tersebut sebagai bagian dari penyelenggaraan rekam medis tersebut.

Penelitian ini menggunakan metode kualitatif dengan pendekatan yuridis sosiologis, yang dilakukan di Kabupaten Temanggung, khususnya di Rumah Sakit Umum Daerah Kabupaten Temanggung. Penelitian ini menggunakan studi lapangan dan studi kepustakaan, data yang telah diperoleh dalam penelitian ini kemudian dianalisis dengan cara lebih menekankan aspek yuridis namun sekaligus membahas aspek sosiologis.

Dasar hukum dan Perundang-undangan penyelenggaraan rekam medis dimulai dari UUD tahun1945, Undang-undang Nomor 36 Tahun 2009, Undang-undang Nomor 29 Tahun 2004, Undang-undang Nomor 44 Tahun 2009 dan Peraturan Menteri Kesehatan Nomor 269 Tahun 2008. Pengaturan mengenai rekam medis meliputi tata cara penyelenggaraan rekam medis, penyimpanan dokumen dan juga penanggungjawab terhadap rekam medis tersebut.Pengaturan rekam medis tersebut berlaku untuk semua sarana pelayanan kesehatan dan juga petugas kesehatan yang terlibat langsung dalam pelayanan kesehatan pasien atau masyarakat pengguna jasa pelayanan kesehatan, tidak terkecuali pelayanan kesehatan yang dilakukan pada pelayanan kesehatan bakti sosial. Penyelenggaraan rekam medis bakti sosial di dalam lingkungan rumah sakit sudah berjalan sesuai peraturan perundangan, sedangkan yang di luar rumah sakit belum berjalan sesuai amanah Undang-undang. Mengenai Penanggungjawab penyelenggaraan rekam medis yang di laksanakan di dalam rumah sakit sudah dilakukan pencatatan hasil pelayanan dan telah dilakukan penyimpanan dokumen rekam medis sedangkan pelaksanaan di luar lingkungan rumah sakit belum dilaksanakan pencatatan dan penyimpanan dokumen rekam medis. Faktorfaktor yang mempengaruhi meliputi sumber daya manusia (SDM), serta sarana dan prasarana. Pelaksanaan di dalam rumah sakit tidak ditemui kendala, namun di luar rumah sakit masih ditemui kendala yaitu SDM, sarana dan prasarana.
\end{abstract}

Kata kunci : Bakti Sosial, Rekam Medis, Pelayanan Kesehatan, Rumah Sakit. 


\section{PENDAHULUAN}

\section{Latar Belakang}

Tujuan nasional Indonesia adalah memajukan kesejahteraan umum mencerdaskan kehidupan bangsa, dan ikut menjaga ketertiban dunia seperti yang tercantum di dalam Pembukaan Undang-Undang Dasar Negara Republik Indonesia tahun 1945. Kesejahteraan umum sendiri memiliki arti keamanan, ketentraman, terpenuhinya kebutuhan serta kesehatan. Agar seorang manusia dapat hidup secara produktif dan dapat beraktifitas maka dibutuhkan kesehatan. Dalam mewujudkan kesehatan tentunya diperlukan upaya-upaya seperti promotif, preventif, kuratif dan rehabilitatif. Bambang Poernomo menyebutkan tentang upaya kesehatan dalam hukum kesehatan bahwa "upaya kesehatan merupakan kegiatan untuk memelihara dan meningkatkan kesehatan yang dilakukan oleh pemerintah dan atau oleh masyarakat dengan mempergunakan jasa tenaga kesehatan"1.

Rumah sakit merupakan institusi yang berperan di dalam pelayanan kesehatan. Soekidjo Notoatmojo menyebutkan bahwa pengaturan penyelenggaraan rumah sakit lebih mengutamakan fungsi sosial yang bertujuan :

a. Mempermudah akses masyarakat untuk mendapatkan pelayanan kesehatan.

b. Memberikan perlindungan terhadap keselamatan pasien, masyarakat, lingkungan rumah sakit dan sumber daya manusia di rumah sakit.

c. Meningkatkan mutu dan mempertahankan standar pelayanan rumah sakit.

d. Memberikan kepastian hukum kepada pasien, masyarakat, sumber daya menusia rumah sakit, dan rumah sakit ${ }^{2}$.

Mengutip dari Undang-undang Nomor 44 Tahun 2009 Pasal 29 butir (f) bahwa setiap rumah sakit mempunyai berbagai kewajiban yang harus dilaksanakan, diantaranya adalah:

"melaksanakan fungsi sosial rumah sakit antara lain dengan memberikan fasilitas pelayanan pasien tidak mampu/miskin, pelayanan gawat darurat tanpa uang muka, ambulans gratis, pelayanan korban bencana dan kejadian luar biasa, atau bakti sosial bagi misi kemanusiaan".

Menurut Endang Wahyati fungsi sosial rumah sakit dapat diartikan sebagai berikut "bagian dari tanggungjawab yang melekat pada setiap rumah sakit yang merupakan ikatan moral dan etik dari rumah sakit dalam membantu pasien khususnya yang kurang/tidak mampu untuk memenuhi kebutuhan akan pelayanan kesehatan"'3. Rumah sakit memiliki kewajiban memberikan pelayanan yang terbaik, sehingga dibutuhkan pelayanan yang bermutu dan berkualitas. Salah satu bagian yang penting di dalam pelayanan rumah sakit adalah terlaksananya penyelenggaraan rekam medis yang baik dan sesuai dengan ketentuan serta peraturan yang berlaku. Rekam medis berisi tentang segala informasi yang selanjutnya dipakai sebagai dasar perencanaan, analisis, menilai kualitas pelayanan yang diberikan kepada seorang pasien. Rekam medis juga dapat melindungi kepentingan hukum baik ditinjau dari segi pasien, sarana pelayanan kesehatan maupun tenaga kesehatan yang secara langsung menangani seorang pasien.

Setiap dokter yang menjalankan praktik kedokteran wajib membuat rekam medis. Rekam medis harus segera dilengkapi setelah pasien selesai menerima pelayanan kesehatan. Di dalam Undang-undang Nomor 29 tahun 2004 Pasal 46 ayat (1) tentang Praktik Kedokteran dan Permenkes Nomor 269 tahun 2008 Pasal 15 ayat (1) disebutkan bahwa "Setiap dokter atau dokter gigi dalam menjalankan praktik kedokteran wajib membuat rekam medis". Namun di dalam

\footnotetext{
1 Bambang Poernomo, Hukum Kesehatan, Program Pendidikan Pasca Sarjana,FK, Magister Managemen Rumah Sakit, Jogjakarta:UGM, Hal.25

2 Soekidjo Notoatmojo, 2010, Etika Dan Hukum Kesehatan, Jakarta: Rineka Cipta, Hal.155

3 Endang Wahyati Yustina, 2012, Mengenal Hukum Rumah Sakit, Bandung: Keni Media, Hal.22
} 
pelaksanaan pelayanan kesehatan bakti sosial biasanya jarang atau bahkan tidak dilaksanakan pembuatan rekam medis. Dari hal tersebut maka, penulis tertarik untuk mengadakan penelitian dengan judul "PENYELENGGARAAN REKAM MEDIS PADA PELAYANAN KESEHATAN BAKTI SOSIAL OLEH RUMAH SAKIT UMUM DAERAH KABUPATEN TEMANGGUNG”.

\section{Perumusan Masalah}

Dari uraian latar belakang sebagaimana tersebut di atas, maka dapat dirumuskan berbagai permasalahan sebagai berikut:

1. Bagaimana pengaturan mengenai penyelenggaraan rekam medis pada pelayanan kesehatan bakti sosial?

2. Siapa yang bertanggungjawab dalam penyelenggaraan rekam medis pada pelayanan kesehatan bakti sosial?

3. Faktor-faktor apa yang mempengaruhi proses penyelenggaraan rekam medis pada pelayanan kesehatan bakti sosial?

\section{Tujuan Penelitian}

1. Mengetahui pengaturan mengenai penyelenggaraan rekam medis pada pelayanan kesehatan bakti sosial .

2. Mengetahui siapa yang bertanggungjawab dalam penyelenggaraan rekam medis pada pelayanan kesehatan bakti sosial.

3. Mengetahui faktor-faktor apa yang mempengaruhi proses penyelenggaraan rekam medis pada pelayanan kesehatan bakti sosial.

\section{Manfaat Penelitian}

1. Manfaat Akademis

a. Bagi Dokter dan Tenaga Kesehatan: diharapkan dokter dan dokter gigi memahami dan dapat melaksanakan kewajibannya dalam pembuatan rekam medis sesuai yang diamanatkan Undang-undang.

b. Bagi Rumah Sakit: dapat menambah kajian pustaka mengenai penyelenggaraan rekam medis dalam pelayanan kesehatan.

c. Bagi Masyarakat: mengetahui arti pentingnya penyelenggaraan rekam medis sehingga pasien juga sadar akan hak dan kewajibanya.

2. Manfaat Praktis

a. Penelitian ini diharapkan dapat memperkaya kajian pustaka mengenai hukum kesehatan khususnya penyelenggaraan rekam medis pelayanan kesehatan bakti sosial.

b. Hasil penelitian ini diharapkan dapat memberi informasi dan masukan bagi peneliti yang lain yang nantinya akan meneliti masalah yang serupa serta dapat menambah referensi di bidang ilmu pengetahuan khususnya hukum kesehatan.

\section{Metode Penelitian}

Maria W.Soemarjono menyatakan bahwa ada dua metode dalam penelitian, yaitu metode kuantitatif dan metode kualitatif ${ }^{4}$.

Metode kualitatif adalah jenis penelitian yang temuan- temuannya tidak diperoleh melalui prosedur statistik atau bentuk hitungan lainnya, melainkan dari data-data yag diperoleh dan yang dikumpulkan dengan mempergunakan beberapa pilihan sarana seperti wawancara, dokumen, buku, kaset vidio, dan data sensus ${ }^{5}$.

4 Maria W. Soemarjono, 1996, Pedoman Pembuatan Usulan Penelitian, Jakarta:PT. Gramedia, hal.19-23

5 Anselmus Strauss dan Juliet Corbin, 2003, Dasar-dasar Penelitian Kualitatif, Yogjakarta:Puataka Pelajar, hal.4 
Penelitian ini akan menggunakan metode kualitatif untuk memahami dan mengungkap mengenai penyelenggaraan rekam medis dan lebih mendalami tentang penyelenggaraan rekam medis pelayanan kesehatan pada bakti sosial.

\section{Metode Pendekatan}

Metode pendekatan yang digunakan dalam penelitian ini adalah yuridis sosiologis. Dalam penelitian ini analisis yang digunakan dengan cara lebih menekankan aspek yuridis namun sekaligus membahas aspek sosiologis. Dalam hal ini pembahasan lebih difokuskan pada penyelenggaraan rekam medis pelayanan kesehatan pada bakti sosial. Informasi didapatkan dari dokter, dokter gigi dan perawat yang terlibat secara langsung dalam memberikan pelayanan kesehatan pasien pada pelayanan kesehatan bakti sosial yang diselenggarakan oleh Rumah Sakit Umum Daerah Kabupaten Temanggung.

\section{Spesifikasi Pendekatan}

Spesifikasi dari penelitian ini adalah deskriptif, dimana penelitian ini dapat menggambarkan suatu keadaan yang akan dijadikan objek penelitian. Penelitian deskriptif menurut Soekidjo Notoatmojo adalah "suatu metode penelitian yang dilakukan dengan tujuan utama untuk membuat gambaran atau mendeskripsikan tentang suatu keadaan secara

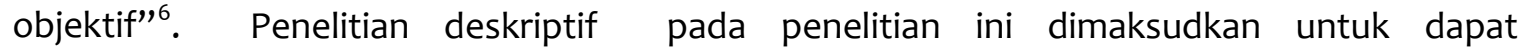
menggambarkan bagaimana penyelenggaraan rekam medis pada pelayanan kesehatan bakti sosial, sekaligus menganalisis apakah sudah ada penyelenggaraan rekam medis dalam pelayanan kesehatan bakti sosial.

\section{Desain Penelitian}

Desain penelitian adalah suatu rencana mengenai keadaan/kondisi untuk mengumpulkan dan analisis data dalam suatu cara untuk menyatukan hubungan (atau perlunya) maksud/tujuan penelitian dengan menghemat dalam prosedur ${ }^{7}$. Pengumpulan data dilakukan dengan wawancara terhadap responden dan analisis datanya menggunakan analisis kualitatif. Soekidjo Notoatmojo menjelaskan bahwa "Analisis kualitatif dapat dilakukan melalui cara induktif yakni pengambilan kesimpulan umum berdasarkan hasil-hasil observasi yang khusus" 8 .

\section{PEMBAHASAN}

\section{A. Peraturan Mengenai Pengaturan Penyelenggaraan Rekam Medis Pada Pelayanan Kesehatan Bakti Sosial}

Dasar hukum pada penyelenggaraan rekam medis pelayanan kesehatan yang diselenggarakan fasilitas pelayanan kesehatan yang salah satunya adalah rumah sakit, dapat dilihat dari peraturan perundang-undangan sebagai berikut:

1) Undang-undang Dasar Negara Republik Indonesia Tahun 1945

Pasal 28 Huruf $\mathrm{H}$ : "Setiap orang berhak hidup sejahtera lahir dan batin, bertempat tinggal, dan mendapatkan lingkungan hidup yang baik dan sehat serta berhak memperoleh pelayanan kesehatan".

2) Undang-Undang Nomor 36 Tahun 2009 tentang Kesehatan.

Pasal 4 : "Setiap orang berhak atas kesehatan".

Pasal tersebut di atas dapat diketahui bahwa setiap orang berhak mendapatkan pelayanan kesehatan termasuk masyarakat yang berada di wilayah Kabupaten Temanggung.

6 Soekidjo Notoatmojo, 2005, Metodologi Penelitan Kesehatan, Jakarta :Rineka Cipta, hal.138

7 Rianto Adi, 2005, Metodologi Penelitian Sosial dan Hukum, Jakarta: Granit, hal. 100

8 Soekidjo Notoatmojo, Op.Cit, hal.186 
3) Undang-undang Nomor 44 Tahun 2009 tentang Rumah Sakit

Mengutip dari Undang-undang Nomor 44 Tahun 2009 Pasal 29 butir (f) bahwa setiap rumah sakit mempunyai berbagai kewajiban yang harus dilaksanakan, diantaranya adalah: "melaksanakan fungsi sosial rumah sakit antara lain dengan memberikan fasilitas pelayanan pasien tidak mampu/miskin, pelayanan gawat darurat tanpa uang muka, ambulans gratis, pelayanan korban bencana dan kejadian luar biasa, atau bakti sosial bagi misi kemanusiaan".

Dari Pasal tersebut di atas dapat ketahui bahwa rumah sakit dalam menjalankan operasinya dalam memberikan pelayanan kesehatan kepada masyarakat, tentunya memiliki sejumlah kewajiban yang antara lain adalah melaksanakan fungsi sosialnya.

4) Undang-undang Nomor 29 Tahun 2004 Tentang Praktik Kedokteran Pasal 46.

(1) Setiap dokter dan dokter gigi dalam menjalankan praktik kedokteran wajib membuat rekam medis

(2) Rekam medis sebagaimana dimaksud pada ayat (1) harus segera dilengkapi setelah pasien selesai menerima pelayanan kesehatan.

(3) Setiap catatan rekam medis harus dibubuhi nama, waktu dan tandatangan petugas yang memberikan pelayanan atau tindakan.

5) Peraturan Menteri Kesehatan Nomor 269 Tahun 2008 Tentang Rekam Medis Pasal 5.

(1) Setiap dokter dan dokter gigi dalam menjalankan praktik kedokteran wajib membuat rekam medis.

(2) Rekam medis sebagaimana dimaksud pada ayat (1) harus dibuat segera dan dilengkapi setelah pasien menerima palayanan.

(3) Pembuatan rekam medis sebagaimana dimaksud pada ayat (2) dilaksanakan melalui pencatatan dan pendokumentasian hasil pemeriksaan, pengobatan, tindakan, dan pelayanan lain yang telah diberikan kepada pasien.

(4) Setiap pencatatan ke dalam rekam medis harus dibubuhi nama, waktu dan tandatangan dokter, dokter gigi atau tenaga kesehatan tertentu yang memberikan pelayanan kesehatan secara langsung.

6) Pasal 6 menyebutkan bahwa dokter dan dokter gigi dan/atau tenaga kesehatan tertentu bertanggungjawab atas catatan dan/atau dokumen yang dibuat pada rekam medis.

\section{B. Pengaturan Penyelenggaraan Rekam Medis Pada Pelayanan Kesehatan Bakti Sosial}

\section{Pelayanan Kesehatan Bakti Sosial di Dalam Rumah Sakit}

Dalam penyelenggaraan rekam medis tersebut di mulai dari pendaftaran pasien, dimana dalam pelaksanaan kegiatan tersebut telah tersedia dokumen rekam medis, telah dilaksanakan pencatatan identitas dan data sosial pasien, hasil pemeriksaan dan pengobatan dan telah dilaksanakan penyimpanan. Pelaksanaan kegiatan tersebut telah berjalan dengan baik dan pelayanan kepada pasien sesuai dengan pelayanan kesehatan ada umumnya yang dilakukan terhadap pasien selain peserta kegiatan bakti sosial. Tenaga kesehatan yang terlibat berasal dari semua disiplin ilmu yang terkait, yaitu dokter, perawat, farmasi, petugas laboratorium dan petugas rekam medis.

Di dalam ketentuan penyelenggaraan rekam medis telah dijelaskan bahwa saat yang pasien datang pada unit pelayanan kesehatan dilakukan pencatatan identitas. Dan pelayanan kesehatan yang dilakukan di dalam lingkungan rumah sakit ini sudah sesuai dengan aturan, yaitu penulisan nama sesuai dengan identitas yaitu KTP/SIM/PASPOR dan menggunakan huruf cetak. Sedangkan dalam sistem penomoran dilakukan pemberian nomor cara unit, dimana pasien diberikan nomor rekam medis pada kunjungan pertama 
dan nomor tersebut akan dipakai untuk kunjungan berikutnya. Rekam medis pelayanan kesehatan bakti sosial yang dilaksanakan di dalam rumah sakit ini, telah dilakukan penyimpanan rekam medis sehingga riwayat pengobatan pasien dapat berkesinambungan.

\section{Pelayanan Kesehatan Bakti Sosial di Luar Rumah Sakit}

Berdasarkan hasil penelitian mengenai Penyelenggaraan Rekam Medis, maka ada beberapa ketentuan Perundang-undangan yang mengatur pelaksanaan rekam medis, aturan tersebut adalah UUD Tahun 1945, Undang-undang Kesehatan, Undang-undang Rumah Sakit, Undang-undang Praktik Kedokteran dan Peraturan Menteri Kesehatan tentang rekam medis.

Berdasarkan hasil penelitian dapat diketahui bahwa semua dokter dan dokter gigi mengetahui tentang aturan pembuatan rekam medis dalam setiap melakukan pelayanan kesehatan. Namun dalam pelaksanaan kegiatan pelayanan kesehatan bakti sosial pelayanan kesehatan yang dilakukan di luar lingkungan rumah sakit belum dilaksanakan pencatatan identitas, belum dilakukan pencatatan hasil pemeriksaan dan pengobatan, hal ini dikarenakan tidak tersediannya dokumen rekam medis dan belum adanya standar prosedur operasional tentang penulisan hasil pemeriksaan dan pengobatan pada rekam medis.

Pelayanan kesehatan bakti sosial yang dilaksanakan di luar RSUD Kabupaten Temanggung jauh dari standar dan belum sesuai peraturan perundangan, hal ini terbukti dengan belum dicatatanya hasil pelayanan di dalam dokumen rekam medis, baik untuk pencatatan identitas maupun pencatatan hasil pemeriksaan dan pengobatan yang dilakukan terhadap pasien.

Dalam Undang-undang rumah sakit telah dijelaskan bahwa rumah sakit memiliki kewajiban menyelenggarakan rekam medis. Dalam Undang-undang Praktik Kedokteran juga telah dijelaskan bahwa setiap dokter dan dokter gigi dalam melakukan praktik kedokteran wajib membuat rekam medis. Dengan keluarnya Permenkes Nomor 269 Tahun 2008 tentang rekam medis maka setiap dokter, dokter gigi dan tenaga kesehatan tertentu yang melakukan tindakan langsung terhadap pasien diwajibkan patuh terhadap ketentuan ini baik segi pemahaman maupun pelaksanaannya. Di dalam buku pedoman penyelenggaraan rekam medis dijelaskan bahwa penulisan nama pasien harus sesuai dengan SIM/KTP/PASPOR yang berlaku dan penulisan nama pasien menggunakan ejaan yang disempurnakan dan ditulis dengan huruf cetak. Selain nama dalam penulisan identitas pasien juga mencantumkan alamat lengkap dan keluarga terdekat. Selain penulisan nama dalam buku pedoman tersebut juga mencantumkan nomor rekam medis yang mana pemberian nomor nomor rekam medis tersebut. Pemberian nomor rekam medis tersebutmeliputi beberapa cara yaitu dengan cara seri, cara unit cara seri unit.

\section{Penanggungjawab Penyelenggaraan Rekam Medis Pada Pelayanan Kesehatan Bakti Sosial}

Penanggungjawab rekam medis dibagi menjadi dua yaitu:

1. Penanggungjawab penulisan hasil pelayanan ke dalam rekam medis.

2. Penanggungjawab penyimpanan rekam medis.

Dalam Peraturan Menteri Kesehatan tentang Rekam Medis Pasal 6 disebutkan bahwa dokter, dokter gigi dan/atau tenaga kesehatan tertentu bertanggungjawab atas catatan dan/atau dokumen yang dibuat pada rekam medis. Dalam peraturan tersebut telah dijelaskan bahwa dalam hal pencatatan kegiatan pelayanan yang dilakukan terhadap pasien menjadi tanggungjawab dokter, dokter gigi dan petugas kesehatan tertentu yang terlibat langsung dalam pelayanan. 
Dalam Undang-undang Praktik Kedokteran Pasal 46 dan Permenkes tentang Rekam Medis Pasal 5 telah dijelaskan bahwa setiap dokter dan dokter gigi dalam melakukan praktik kedokteran wajib membuat rekam medis, hal ini berarti ada keharusan pembuatan rekam medis oleh dokter dan dokter gigi dalam setiap melakukan praktik kedokteran, tanpa terkecuali praktik kedokteran yang dilaksanakan di dalam pelayanan kesehatan bakti sosial.

Pasal 2 ayat (6) Permenkes Nomor 269 tahun 2008 menyebutkan bahwa pelayanan yang diberikan di dalam ambulans atau pengobatan masal dicatat dalam rekam medis sesuai dengan ketentuan sebagaimana diatur pada ayat (3) dan disimpan pada sarana pelayanan kesehatan yang merawatnya. Dalam penelitian ini pelayanan kesehatan bakti sosial yang menyelenggarakan adalah RSUD Kabupaten Temanggung, maka yang bertanggungjawab dalam penyimpanan buku register dan dokumen rekam medis adalah Rumah Sakit Umum Daerah Kabupaten Temanggung sebagai penyelenggara kegiatan tersebut.

\section{Faktor-faktor Yang Mempengaruhi Proses Penyelenggaraan Rekam Medis Pada Pelayanan Kesehatan Bakti Sosial}

\section{Faktor Yuridis}

Dalam Permenkes disebutkan bahwa yang bertanggungjawab atas catatan dan/atau dokumen yang dibuat adalah dokter, dokter gigi dan petugas kesehatan lainnya yang turut serta dalam pelayanan langsung kepada pasien. Dalam pelaksanaan pelayanan kesehatan yang dilakukan di dalam lingkungan rumah sakit sudah sesuai dengan ketentuan yang berlaku. Dalam pelaksanaan kegiatan pelayanan kesehatan bakti sosial di luar lingkungan rumah sakit ini yang menyelenggarakan adalah rumah sakit maka yang bertanggungjawab adalah RSUD Kabupaten Temanggung.

\section{Faktor Teknis}

Dalam melaksanakan pelayanan kesehatan bakti sosial perlu adanya beberapa faktor yang dapat mendukung pelaksanaan kegiatan tersebut. Faktor-faktor pendukung tersebut antara lain adalah :

1. Sumber Daya Manusia

Dari hasil penelitian yang dilakukan oleh RSUD Kabupaten Temanggung diperoleh hasil bahwa dalam pelaksanaan kegiatan di luar lingkungan rumah sakit tersebut SDM yang terlibat kurang. Dimana petugas yang terlibat meliputi dokter, dokter gigi, perawat dan perawat gigi, sedangkan petugas farmasi dan petugas rekam medis tidak dilibatkan. Sehingga terjadi rangkap tugas dan pelayanan menjadi kurang maksimal.

2. Sarana dan Prasarana

Dalam melaksanakan kegiatan yang telah direncanakan seperti pelayanan kesehatan bakti sosial tentunya memerlukan peralatan yang cukup aman dan nyaman. Pelayanan kesehatan bakti sosial yang dilaksanakan di dalam lingkungan rumah sakit tidak ditemukan permasalahan karena peralatan yang digunakan sudah memadai. Dan pelayanan kesehatan bakti sosial yang dilaksanakan di luar rumah sakit belum tersedia saran dan prasarana yang memadai. 


\section{PENUTUP}

\section{KESIMPULAN}

\section{Pengaturan Penyelenggaraan Rekam Medis Pada Pelayanan Kesehatan Bakti Sosial}

Dalam Undang-undang rumah sakit, Undang-undang Praktik kedokteran serta Permankes 269 Tahun 2008 tentang rekam medis maka setiap dokter, dokter gigi dan tenaga kesehatan tertentu yang melakukan tindakan langsung terhadap pasien diwajibkan patuh terhadap ketentuan ini. Namun dalam pelaksanaan pelayanan kesehatan bakti sosial yang dilaksanakan di luar RS, belum semua tenaga kesehatan membuat rekam medis. Pelayanan kesehatan bakti sosial yang dilaksanakan di dalam RS, telah tersedia dokumen rekam medis yang sesuai dengan standar dokumen rekam medis.

2. Pihak Yang Bertanggungjawab Dalam Penyelenggaraan Rekam Medis Pada Pelayanan Kesehatan Bakti Sosial

Dalam Permenkes tentang Rekam Medis Pasal 6 disebutkan bahwa dokter, dokter gigi dan/atau tenaga kesehatan tertentu bertanggungjawab atas catatan dan/atau dokumen yang dibuat pada rekam medis. Namun di dalam pelayanan kesehatan bakti sosial yang dilaksanakan di luar lingkungan rumah sakit belum semua tenaga kesehatan mencatat hasil pemeriksaan dan pengobatan. Pelayanan kesehatan bakti sosial yang dilaksanakan di dalam rumah sakit telah dilakukan pencatatan hasil pemeriksaan dan pengobatan sesuai peraturan yang berlaku.

Pasal 2 ayat (6) Peraturan Menteri Kesehatan Nomor 269 tahun 2008 menyebutkan bahwa pelayanan yang diberikan di dalam ambulans atau pengobatan masal dicatat dalam rekam medis sesuai dengan ketentuan sebagaimana diatur pada ayat (3) dan disimpan pada sarana pelayanan kesehatan yang merawatnya.

3. Faktor-faktor yang Mempengaruhi Proses Penyelenggaraan Rekam Medis Pada Pelayanan Kesehatan Bakti Sosial

\section{a. Faktor Yuridis}

Peraturan mengenai kewajiban menyelenggarakan rekam medis diatur dalam Undang-Undang No. 29 Tahun 2004 tentang prakti kedokteran dan Permenkes No. 269 Tahun 2008 tentang rekam medis.

\section{b. Faktor Teknis}

Faktor teknis dalam penelitian ini terdiri dari sumber daya manusia (SDM) dan sarana prasarana. SDM yang disiapkan dalam melaksanakan pelayanan kesehatan bakti sosial kurang memadai atau jumlahnya dan jenis tenaga.

\section{SARAN}

1. Bagi Rumah Sakit

a. Perlu Kebijakan/Keputusan Direktur mengenai pelayanan kesehatan bakti sosial, baik yang diselenggarakan di dalam maupun di luar lingkungan rumah sakit.

b. Perlu SPO tentang penyelenggaraan rekam medis baik yang dilaksanakan di dalam maupun di luar lingkungan rumah sakit.

c. Berkas rekam medis perlu dibuat standar, baik yang digunakan dalam pelayanan kesehatan di rumah sakit maupun pelayanan kesehatan bakti sosial. 
2. Bagi Penyelenggara Kegiatan Pelayanan Kesehatan Bakti Sosial di luar institusi kesehatan

a. Dalam penyelenggaraan pelayanan kesehatan bakti sosial perlu melibatkan institusi kesehatan setempat dalam hal penyelenggaraan rekam medis maupun penyimpanan rekam medis dan berkas yang berhubungan dengan pelayanan kesehatan bakti sosial tersebut.

b. Dalam menyelenggarakan pelayanan kesehatan bakti sosial perlu persiapan: formulir rekam medis, sistem penamaan, sistem penomoran.

\section{DAFTAR PUSTAKA}

Adi, Rianto, 2005, Metodologi Penelitian Sosial Dan Hukum, Jakarta : Granit

Dahlan, Sofwan, 2005, Hukum Kesehatan (Rambu-rambu bagi prefesi Kedokteran), Semarang: Badan penerbit UNDIP

Departemen Kesehatan RI, 2006, Pedoman Pengelolaan Rekam Medis Rumah Sakit di Indonesia Revisi II, Jakarta

Fajar, Mukti dan Yulianto Achmad, 2010, Dualisme penelitian Hukum Normatif \& Empiris, Yogyakarta : Pustaka Pelajar

Guwandi, J., 1992, Trilogi Rahasia Kedokteran,Jakarta : Universitas Indonesia

Hartono, Bambang, 2010, Promosi Kesehatan Di Puskesmas \& Rumah Sakit, Jakarta : Rineka Cipta

Hatta, Gemala R., 2008,Pedoman manajemen Kesehatan Di Sarana Pelayanan Kesehatan, Revisi, Jakarta Universitas Indonesia

Herlambang, Susatyo, 2011, Etika Profesi Tenaga Kesehatan, Yogjakarta : Gosyen Publiser

Jayanti, Nusye KI, 2009, Penyelesaian Hukum Dala Malpraktik Kedokteran,Yogjakarta : Pustaka Yustisia

Kamus Besar Bahasa Indonesia, 2001, Balai Pustaka, Jakarta

Koeswadji, Hermin Hadiati, 1992, Beberapa Permasalahan Hukum dan Medik, Bandung : Citra Aditya bakti

Konsil Kedokteran Indonesia, 2006,Manual Komunikasi Efektif Dokter-Pasien, Jakarta

Notoatmodjo, Soekidjo, 2005, Metodologi Penelitian Kesehatan, Jakarta : Rineka Cipta

Notoatmodjo, Soekidjo, 2010, Etika Dan Hukum Kesehatan, Jakarta : Rineka Cipta

Poernomo, Bambang, Tanpa Tahun, Hukum Kesehatan, Yogyakarta: Program Pendidikan Pascasarjana, Fakultas Kedokteran Magister Manajemen Rumah Sakit UGM

Soemardjono, Maria W, 1996, Pedoman Pembuatan Usulan Penelitian, Jakarta : Gramedia

Soemitro, Ronny Hanitijo, 1998, Metodologi Pemelitian Hukum dan Jurimetri, Jakarta : Ghalia Indonesia

Soewondo, Hendrojono, 2007,Batas Pertanggungjawaban Hukum Malpraktik Dokter dalam Transaksi Terapeutik, Surabaya: Srikandi

Statistik Kabupaten Temanggung, 2012, Temanggung Dalam Angka

Strauss, Anselmus dan Juliet Corbin, 2003, Dasar - dasar Penelitian Kualitatif, Yogyakarta : Pustaka Pelajar 
Sumantri, Arif, 2001, Metodologi Penelitian Kesehatan, Jakarta : Prenada Media

Sunggono, Bambang, 2007, Metodologi Penelitian Hukum, Jakarta : Rajagrafindo Persada Tengker, Freddy, 2007, Hak Pasien, Bandung : Mandar Maju

Wijaya, Hari dan Triton, 2005, Pedoman Skripsi Tesis, Yogyakarta : Tugu Publiser

Yustina, Endang Wahyati, 2012, Mengenal Hukum Rumah Sakit, Bandung : Keni Media

\section{PERUNDANG-UNDANGAN}

Undang-Undang Dasar 1945

Undang-Undang Nomor 44 Tahun 2008 tentang Rumah Sakit

Undang-Undang Nomor 36 Tahun 2009 tentang Kesehatan

Undang-Undang Nomor 44 Tahun 2009 tentang Praktik Kedokteran

Peraturan Menteri Kesehatan Nomor 269 Tahun 2008 tentang Rekam Medis

Peraturan Menteri Kesehatan Nomor 340 Tahun 2010 tentang Klasifikasi Rumah Sakit

\section{SUMBER INTERNET}

http://baguspemudaindonesia.blogdetik.com/2011/04/20/manusia-dan-tanggung-jawab/ 